\title{
On the Discrete Analysis of the Jointed Rock Media
}

\author{
Ryokichi HAMAJIMA* and Tadahiko KAWAI**
}

節理系岩盤の離散化解析について

浜島良吉・川井忠彦

\begin{abstract}
Stress transfer mechanism of the jointed rock media was studied theoretically and experimentally. The discrete element model used in this study is based on the "rigid body-spring models" proposed by the second author, Kawai five years ago. In these models it is assumed that the elements themselves are rigid and they are connected by two types of springs distributed over their interface boundaries.

Using the well known Mohr-Coulomb's failure criterion and considering the effect of contact as well as separation of individual rock elements, the elasto-plastic analysis was carried out by basing on the initial stress method. It was found that the calculated results were in fairly good agreement with the results of the photoelastic analysis and that the stress distribution of these jointed rock media was considerably different from that of the compressed homogeneous continuous media.
\end{abstract}

\section{INTRODUCTION}

Generally speaking, actual foundation is not homogeneous and discontinuous in structure and mechanical properties, and therefore it is desperately needed to make clear the characteristics of jointed rock media having discontinuity.

A great number of studies have been made on jointed rock media, which include the studies of the shearing strength characteristics by Hayashi (1966), Ladany \& Archanbault (1970) and Barton Choubey (1977), the biaxial and triaxial tests on jointed rock by Brown \& Trollope (1970), and Einstein \& Hirschfeld (1973), the studies of the stress transfer mechanism of jointed rock media by Hayashi (1970), Maury \& Duffout (1970), Bracic (1970), and Kandaourov, Ouvaro \& Karpov (1974).

The analysis of such jointed rock media is, however, still incomplete and therefore these studies are not beyond qualitative discussion.

The methods of numerical analysis for the foundation having the discontinuous properties

* Associate Professor, Department of Construction Engineering, Saitama University, Saitama 338, Japan

** Professor, Institute of Industrial Science, the University of Tokyo, Tokyo 106, Japan are generally classified into the following two groups.

1) the finite element method with the use of joint elements,

2) discrete methods where rigid elements are considered.

The Goodman, Tayler \& Brekke's method of the joint elements (1968) is useful only when the discontinuous surface is already known, and it is not possible to study the slip failure of foundation structures generally.

Kawamoto \& Takeda (1978) proposed a similar method where crack elements are introduced. Their method, however, can be deduced from the Goodman et al's jointed element method.

In contrast with these methods, Cundall (1971) developed a method in which the foundation is idealized as an aggregate of completely discrete rigid elements, and he showed effectiveness in the analysis of a toppling failure of rock.

Independently in 1976 Kawai proposed new discrete model which are called as the Rigid Body-Spring Model (abbreviated as RBSM) by basing on the experimental evidence of solids under the ultimate state of loading. These models consists of rigid bodies and two types of connection springs, one of which resists the normal deformation, while the other the shear deformation. He conducted verification studies of his 
models by solving a series of collapse problems of the beam, plate, shell and three dimensional structures.

They were proved to be very effective for the analysis of the materials having the yield criterion of Mohr-Coulomb's type, because only the normal and shearing stresses are necessary to consider on the element boundary.

Takeuchi (1980) attempted application of the RBSM models to no-tension analysis of the granular media which was originally proposed by Zienkiewicz (1968) and later by adding a scheme for checking on the contact of adjoining elements, he modified his program of the notension analysis and he called it the method of tension-crack analysis. Combined use of his method with the conventional elasto-plastic analysis, however, has not been attempted yet.

In this paper, therefore, considering the effect of re-contact as well as separation of individual rock elements, the elasto-plastic analysis was carried out by basing on the initial stress method by Zienkiewicz, Valliappan \& King (1969).

A study was made by using this method on the stress distribution of the jointed rock media weakened by joints of various patterns, and it was demonstrated by photoelastic experiments that the analysis is also applicable to the case where the foundation is subjected to any confining pressure.

\section{MODEL AND ANALYSIS}

\subsection{RBSM Model}

Now consider two elements shown in Fig. 1. A set of spring system resisting the relative displacements along the normal, tangential direction and in rotation are considered on the boundary surface. The strain energy $\mathrm{V}$ accumulated in the spring system after deformation is given by the following expression:

$$
V=K_{d} \delta_{d}^{2} / 2+K_{s} \delta_{s}^{2} / 2+K_{r} \phi^{2} / 2
$$

The force vector corresponding to the displacement vector $u$ at the center of gravity in each element can be obtained by applying the Casti-

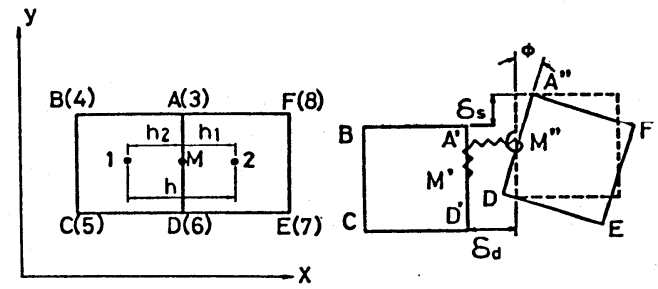

Fig. 1 Rigid Body Spring Model gliano's theorem.

The $K_{d} \delta_{d}, K_{s} \delta_{s}$ and $K_{r} \phi$ 'implies the normal force, shearing force and moment acting on the boundary surface respectively.

These spring constants $K_{d}, K_{s}$ and $K_{r}$ in the Eq. (1) can be given by the Following formula:

$$
\left.K_{d}=A_{s} E / h, \quad K_{s}=A_{s} G / h,\right\}
$$

where $A_{s}$ represents the contact area between elements 1 and 2 and $l_{36}$ the contact length. $E$ and $G$ are Young's modulus and shear modulus respectively. $h=h_{1}+h_{2}$ is the total of of the normal distance extended to the boundary surface of element from the center of gravity of each element.

It should be mentioned here that $K_{r}$ can be expressed in term of Young's modulus $E$, so that only two types of spring $E$ and $G$ are necessary.

Details of the theoretical basis of the RBSM element can be found in the literature listed at the end of this paper.

\subsection{Elasto-Plastic Analysis}

In the analysis of jointed rock media, it is absolutely necessary to consider such non-linear behaviors as opening and slip of the discontinuous surface.

In this paper, the mechanical characteristics of joint surface as shown in Fig. 2 were given together with the following Mohr-Coulomb's yield criterion with tension cut

$$
\tau=C-\sigma_{n} \tan \phi, \quad\left(\sigma_{n}<\sigma_{t}\right)
$$

in which $C, \phi$ and $\sigma_{t}$ represent cohesion, angle of internal friction and tensile strength respectively. When an associated flow rule is assumed where the yield criterion coincides with the plastic potential, the elasto-plastic analysis may become simpler.

It should be mentioned here that elements are assumed to be rigid and then only two stress components $\sigma_{n}$ and $\tau$ are necessary to consider on the interelement boundary.

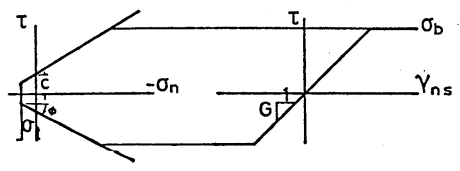

(b)

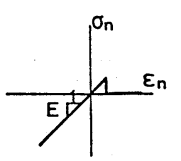

(c)
Fig. 2 Mechanical Models;

(a) Mohr-Coulom's Failure Criterion,

(b) Shear Stress-Strain Relation,

(c) Normal Stress Strain Relation 
Therefore the yield function and consequently expression for the elasto-plastic stiffness matrix of the elements must be modified. Such modification is already given by Kondou (1977).

As already mentioned, the method of notension analysis together with the initial stress method by Zienklewicz, Valliappan \& King (1969) was adopted in this study.

Since the effect of contact among particles should be taken into account in the analysis of granular media development was made on the checking algorism about contact or separation of two adjacent elements.

\section{PHOTOELASTIC EXPERIMENT AND NUMERICAL SOLUTION}

The experimental study was carried out by using a biaxial loading equipment as shown in Photo. 1 where the uniform lateral pressure is applied by using the pressure bags attached to both sides of the test specimen.

An unconfined compression test and a shearing test were further made to determine photoelastic material constants.

Based on the unconfined compression test, Young's modulus $E=550 \mathrm{MPa}$ and Poisson's number $=0.37$ were determined.

Next, the results for shear modulus $G$, angle of internal friction $\phi$ and cohesion $C$ were obtained from the test using the box shear apparatus with a single shear surface.

In this material testing, it was found that the shear modulus $G$ depends on the magnitude of normal stress $\sigma_{n}$, but constant rigidity $G=28.2$ MPa was assumed to make calculation simpler. It was also observed that the maximum shearing strength fluctuate slightly due to stick slip. Accordingly the angle of internal friction $\phi$ varies in the range of $10^{\circ}<\phi<19^{\circ}$, but $\phi=15^{\circ}$ was used in the calculation.

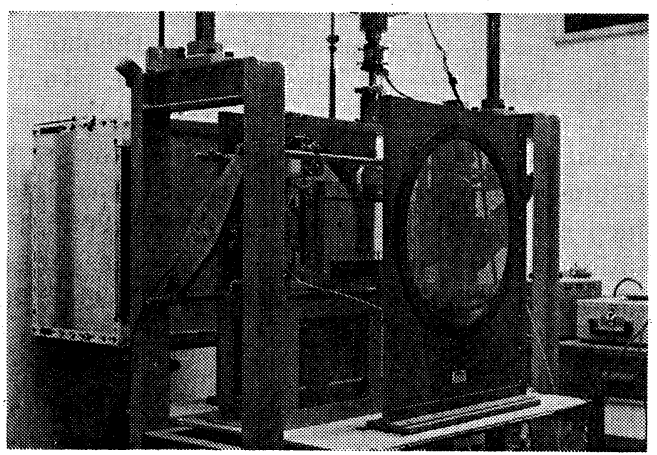

Photo. 1 Biaxial Loading Photoelastic Equipment

\subsection{Numerical and Experimental Results}

Square and disc photoelastic elements were piled up to form the shapes of Type (a) through (e) as shown in Fig. 3 and glass plates were placed in front and rear of the piled elements to prevent their collapse to the outside of the surface. The load was vertically applied to the jointed block model through the plate gap. $(15.2 \mathrm{~mm})$. Colour photographs of these models at several stages of loadings were taken as shown in Photo. 2.

The stress distribution on the bottom of the foundation models was measured by reading the fringe number of the disc plate elements inserted into the model base as shown in Fig. 3. Further
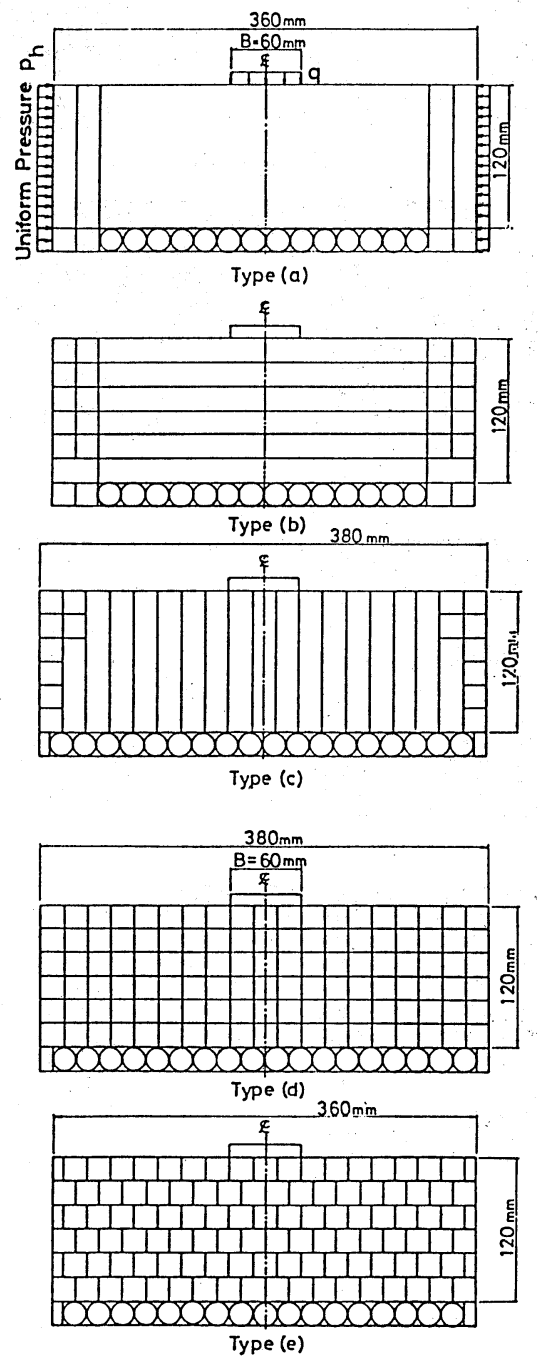

Fig. 3 Experimental Model of Jointed Rock Media 


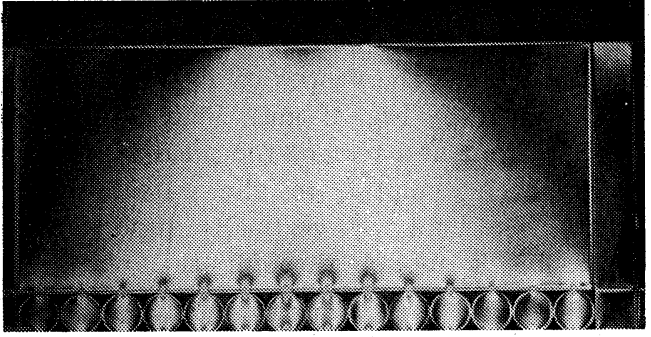

(a) Type-a

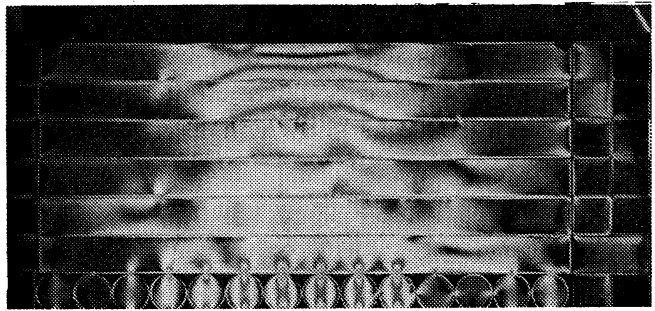

(b) Type-b

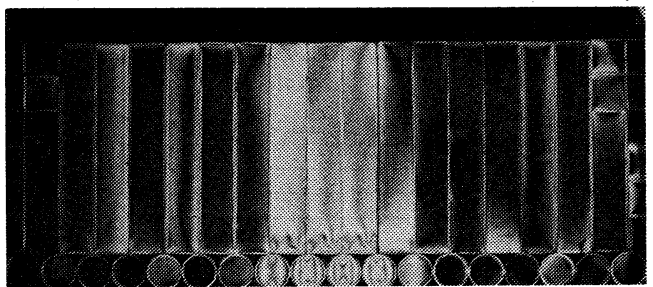

(c) type-c

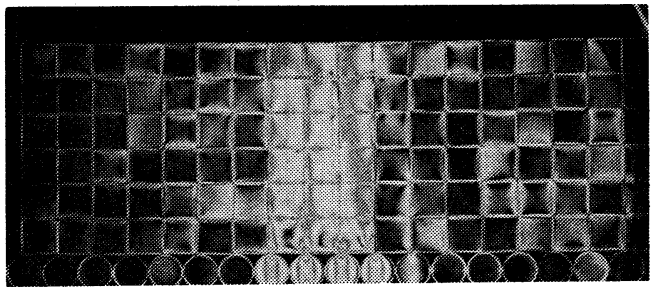

(d) Type-d

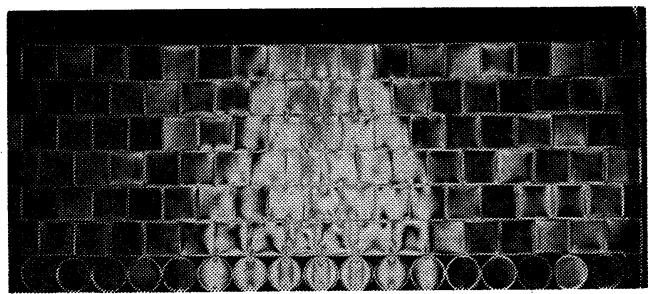

(e) Type-e

Photo. 2 Photoelastic Experimental Results (Lateral Pressure $p_{h}=0$, Surcharge $q=0.56$ MPa).

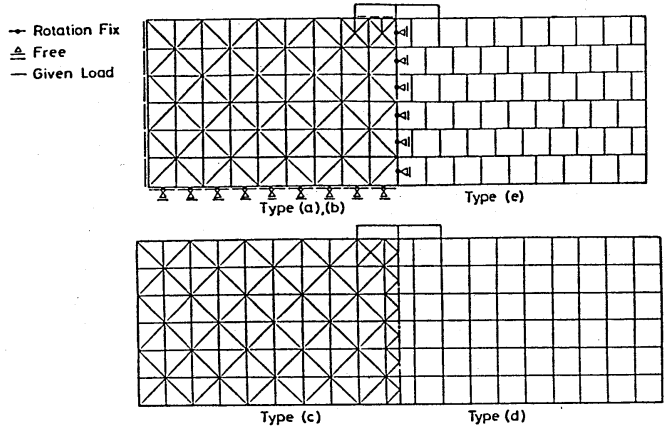

Fig. 4 Mesh Division and Boundary Condition for Calculation

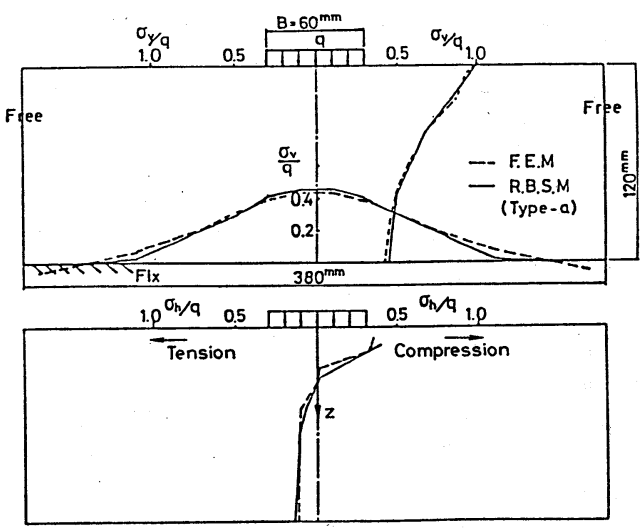

Fig. 5 Vertical Stress $\sigma_{V}$ and Horizontal Stress $\sigma_{h}$ in Homogeneous Foundation.

the block elements inserted between both sides of the models of types (a), (b) and (c) in Fig. 3 have been provided for convenience, because no photoelastic material longer than $300 \mathrm{~mm}$ could be prepared. Their effect on the stress distribution on the base of foundation model can, however, almost be ignored.

Fig. 4 shows the mesh division for the calculation of Types (a), (b), (c), (d) and (e). In the case of Types (b) and (c), the interior of the rod element was further divided, and the shear modulus $G$ on the interior boundary was determined by substituting the value $(G=200 \mathrm{MPa})$ obtained from $G=E / 2(1+\nu)$, as in the case of homogeneous model of Type (a). $\sigma_{t}=C=1000$ $\mathrm{MPa}$ and $\phi=0^{\circ}$ were assumed to prevent slip in the rod element.

Fig. 5 shows a comparison between FEM and this RBSM for a homogeneous model of Type (a), from which good agreement can be seen. It can be concluded from this result that this method 

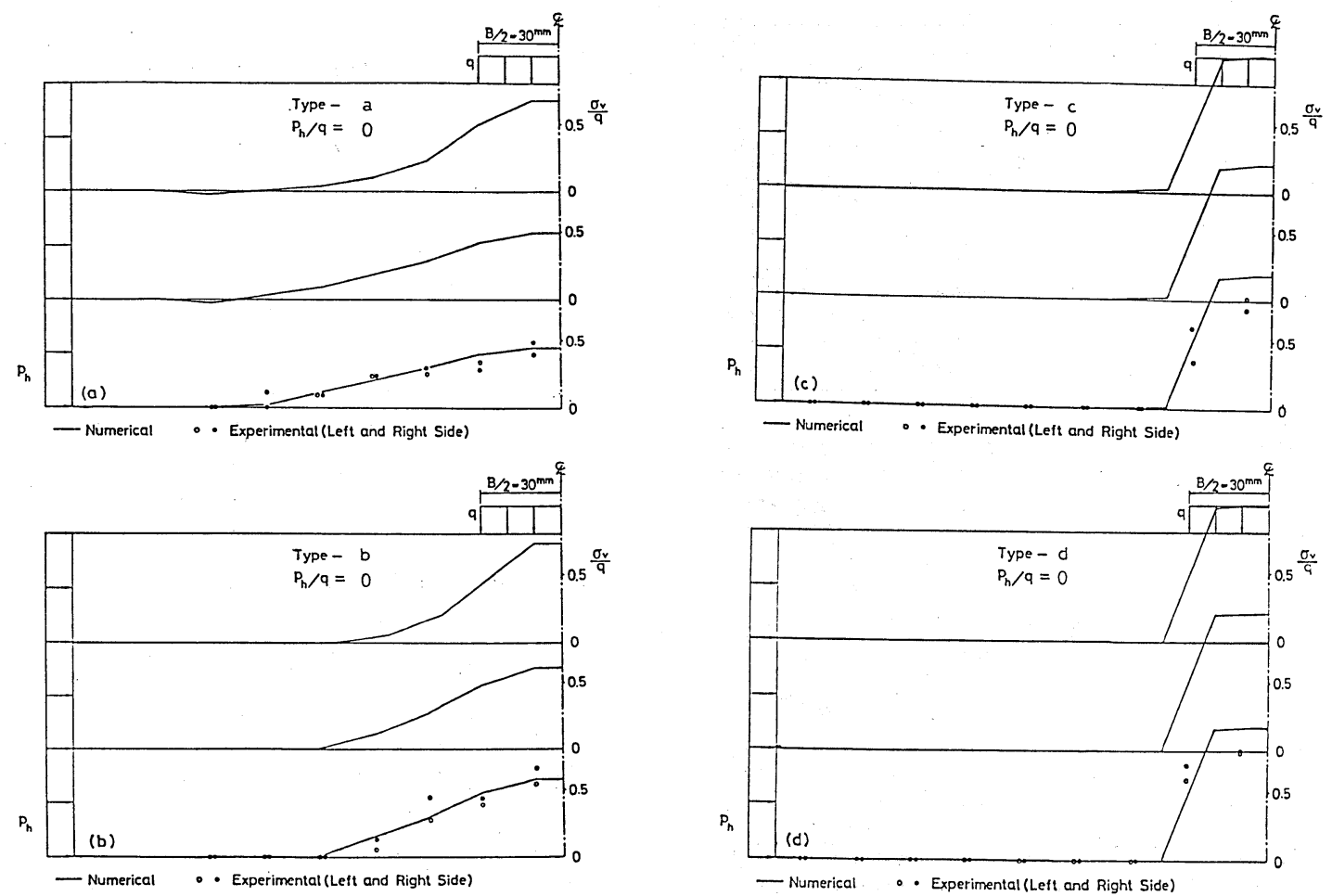

Fig. 6 Distribution of Vertical Contact Stress in the Foundation $(q=0.56 \mathrm{MPa})$.

is well applicable not only to a completely discrete model but also a continuous model. Fig. 5(b) shows the distribution of horizontal stress along the depth of foundation (the $Z$ axis), in which a tensile stress has occurred at the location deeper than the width of loading plate.

Fig. 6 show the vertical stress distribution on the base line of foundation model for each type.

Fig. 6(a) shows the stress distribution in the homogeneous model of Type (a), in which the numerical results showed good agreement with the experimental results.

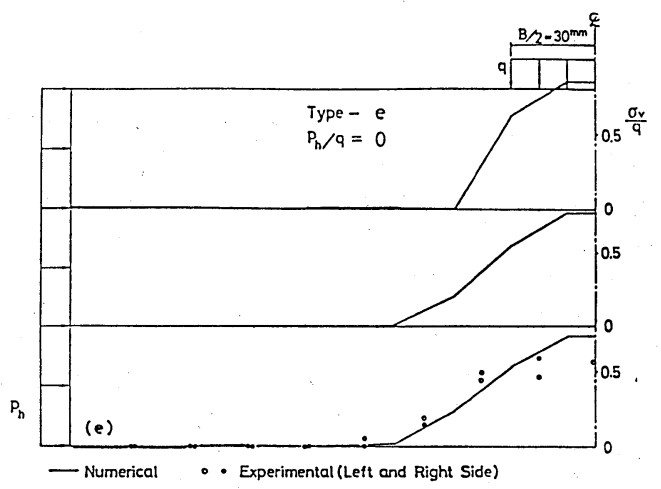

Fig. 6(b) shows the vertical stress distribution of a horizontally layered model of Type(b), which is smaller in the width than that of the uniform model of Type (a). As shown in Fig. 7, however, its vertical stress distribution does not change with the variation of the lateral pressure as in the case of Type (a). This can be also explained by the fact that the patterns of slip and opening as shown in Fig. 9 do not vary with the change in lateral pressure.

Fig. 6 (c) shows the vertical stress distribution in Type (c), in which the vertical load acting on the upper surface of foundation was directly 

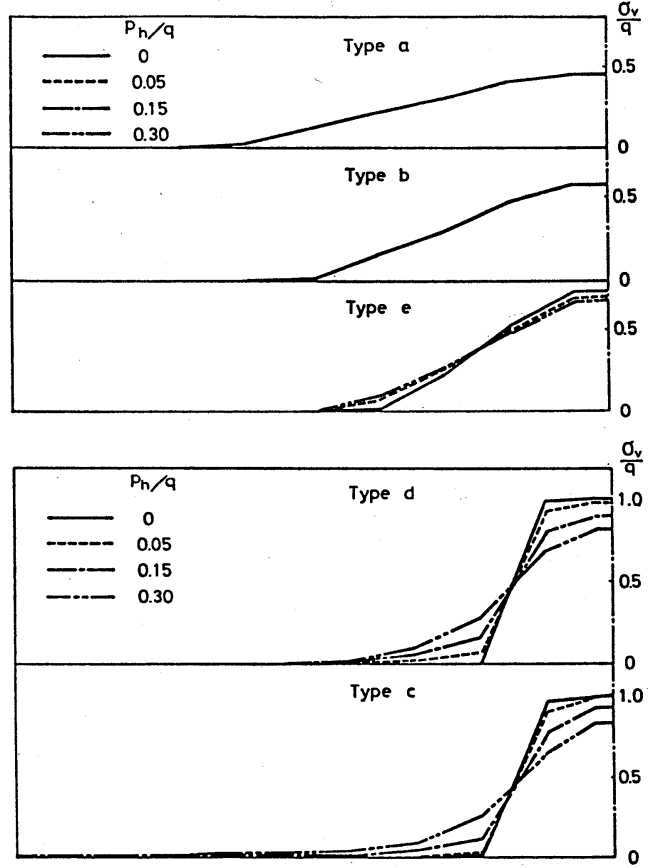

Fig. 7 Comparison for Each Type of Vertical Stress Distribution on the Base Line of Foundation $(q=0.56 \mathrm{MPa})$.

transferred without changing the magnitude to its base when no laternal pressure is applied. In Type (c), the distribution width of vertical stress has increased with the increase of lateral pressure as shown in Fig. 7.

Fig. 6(d) shows the vertical stress distribution in Type (d), which is almost the same as that in a vertically layered model of Type (c). The distribution width under the influence of lateral pressure is also almost the same as in Type (c).

Fig. 6 (e) shows the vertical stress distribution in Type (e), which has intermediate characteristics between Type (b) and Type (d). These characteristcs become more similar to those of Type (b) by increasing the lateral pressure.

Fig. 8 shows the changes of the vertical stress of the center disc element on the base of foundation versus the changes of the lateral pressure applied for all types of models. In the figure, the numerical results showed that the vertical stresses of the center disc elements in Types (c), (d) and (e) decrease as the lateral pressure rises, while those in Types (a) and (b) do not vary with the lateral pressure.

Fig. 9 shows the conditions of slip and opening,

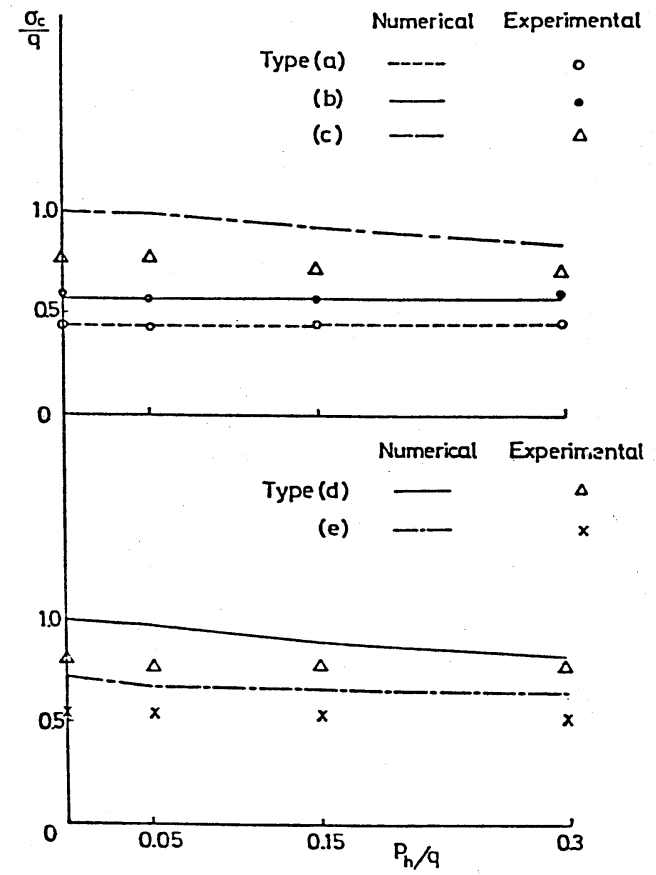

Fig. 8 Vertical Stress at the Center of the Base in Foundation $\sigma_{c}$ versus Lateral Pressure $P_{h}$ $(q=0.56 \mathrm{MPa})$

which will make it possible to study more clearly the stress transfer mechanism. These figures correspond to the plastic zone obtained by the conventional finite element analysis. The relation between the vertical slip pattern and the lateral pressure in Types (d) and (e) of Fig. 9 well represents the characteritics of slip failure in foundation.

\section{CONCLUSION}

The discrete analyses by using the RBSM and the photoelastic experiments were carried out on jointed rock media in various discrete patterns, and the following results have been obtained:

1. The influence of the initial confining pressure or cohesion on the stress distribution in foundation were studied by the photoelastic experiment and the computer simulation of the experimental results obtained was made by using a discrete method of analysis proposed by the present authors. It was found that compared with Cundall's method which is very useful only to a very shallow part of foundation, this method can effectively be used to clarify the stress transfer mechanism 


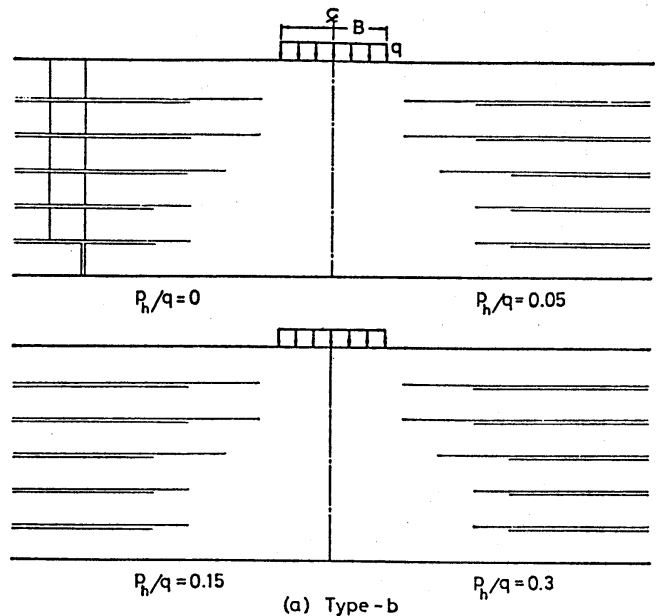

(a) Type - b

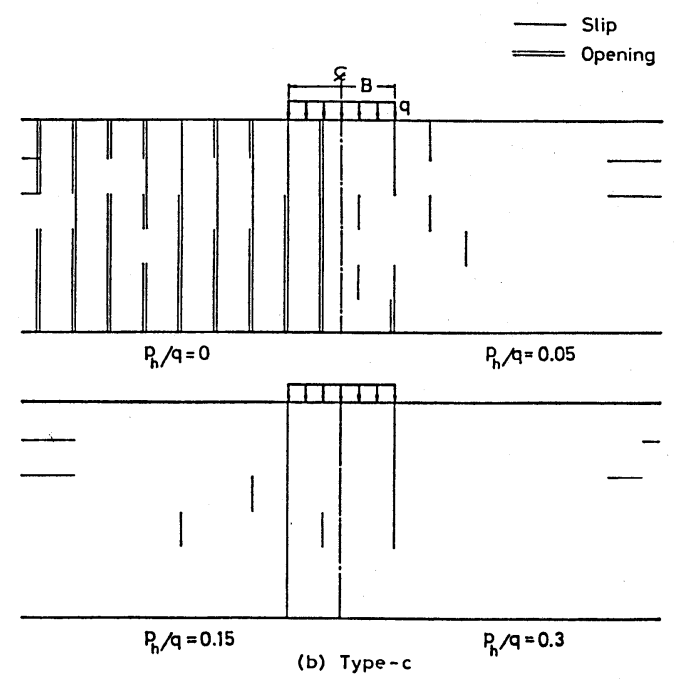

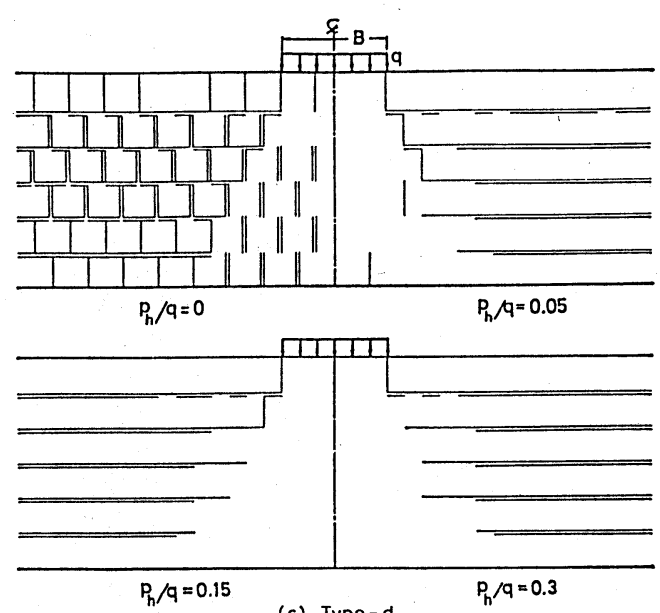

(c) Type-d

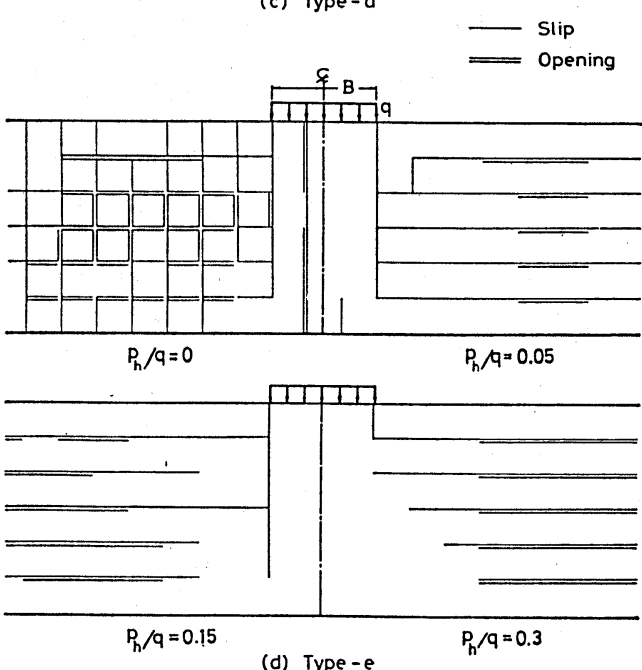

(d) Type-e

Fig. 9 Slip and Opening Pattern. $(q=0.56 \mathrm{MPa})$.

of jointed rock media affected by any confining pressure. In particular, the phenomena of slip and tensile failure could precisely be studied in this paper. These slip and opening patterns are believed to be very useful in understanding the stress transfer mechanism.

2. The stress distribution changes considerably depending on the shape of joint and the variation of the confining pressure.

It can be concluded from these results that proper selection of the model is very important in the study of the jointed rock media which have discontinuous characteristics.

\section{References}

1) Barton, N. R. and Choubey, V. (1977); The Shear Strength of Rock Joints in Theory and Practice, Rock Mechanics, Vol. 10, pp. 1-54.

2) Bracic, V. (1970); Photoelastic Investigations of Discontinuous Rocks, 2nd Cong. on Rock Mech. Sec. 8-23.

3) Brown, E. T. and Trollope, H. (1970); Strength of a Model of Jointed Rock, J. Soil Mech. and Found. Div. Proc. A.S.C.E. SM 2, pp. 685-705.

4) Cundall, P. A. (1971); A Computer model for Simuating Progressive Large-Scale Movements in Blocky Rock Systems, Symposium on Rock Fracture, Nancy, France, October, Section 2-8.

5) Einstein, H. H. and Hirschfeld, R. C. (1973); 
Model Studies on Mechanics of Jointed Rock, J. Soil Mech. and Found. Div., Proc. A.S.C.E. SM 3, Vol. 99, pp. 229-248.

6) Goodman, R. E., Tayler, R. L. and Brekke, T. L. (1968); A Model for the Mechanics of Jointed Rock, J. Soil Mech. and Found. Div., Proc. A.S.C.E. SM 3, pp. 637-659.

7) Hayashi, M. (1966); Strength and Dilatancy of Brittle Jointed Mass-the Extreme Value Stochastics and Anisotropic Failure Mechanism, Proc. 1st Congress Int. Society for Rock Mechanics, Lisbon, Vol. 1, 295-301.

8) Hayashi, M. (1970); A Mechanism of Stress Distribution in the Fissured Foundation, Proc. 1st Cong. Int. Society for Rock Mechanics, Lisbon, Vol. 2, on Rock Mech., pp. 509-516

9) Kandaourov, I. J., Ouvaro, L. A. and Karpov. N. M. (1974); Stress in Models Simulating Thrustless Jointed Rock Masses, Proc. 3rd Congress of Rock Mech., Denver, Vol. 2A, pp 156-160.

10) Kondou, K. (1977); Basic Studies on the discrete analysis of beam and plate elements by using the lower order shape functions, Doctorate Thesis submitted to the University of Tokyo (in Japanese)

11) Kawai (1980); Some Consideration on the Finite Element Method, International Journal for Numerical Methods in Engineering, Vol. 16, pp. 81-119.

12) Kawamoto, T. and Takeda, N. (1978); An Anal ysis of Progressive Failure in Rock Slopes, 3rd Int. Conf. on Numerical Methods in Geomechanics, Achen, pp. 797-808.

13) Ladany, B. and Archanbault, G. (1970); Simulation of Shear behavior of a Jointed Rock Mass, Proc. 11th Symposium on Rock Mech., Published by AIME, New York, pp. 105-125.

14) Maury, V. Duffout, P. (1970); (i) Stress Distribution Model Analysis in a Two-Families Discontinuity Medium, Proc. 2nd Cong. on Rock Mech. Ses., 8-19, (ii) Model Study of Stress Distribution in a Multy-Layer System with Interface Friction, Proc. 2nd Cong. on Rock Mech. Ses. 8-20.

15) Takeuchi, N., and Kawai, T. (1980); Limit Analysis of Soil and Rock Foundations by Means of New Discrete Models-An Analysis of a No-Tension Materials, Journal of the "Seisan Kenkyu", Vol. 32, No. 6 (in Japanese).

16) Takeuchi, N., and Kawai, T. (1981); A Method for the Error Evaluation of the New Discrete Limit Analysis Salutions, Journal of the Seisan
Kenkyu", Vol. 33, No. 2 (in Japanese).

17) Zienkiewicz, O. C., et al. (1968); Stress Analysis of Rock as 'No-Tension' Material, Geotechnique, 18, pp. 56-66.

18) Zienkiewicz, O. C., Valliappan, S. and King, I. P., (1969); Elasto-Plastic Solutions of Engineering Problems Initial Stress Finite Element Approach, Int. Journal for Numerical Methods in Engineering, Vol. 1, 75-100.

19) Zienkiewicz, O. C. and Dullage, C. (1970); Analysis of non-Linear Problems in Rock Mechanics with Particular Reference to Jointed Rock Systems, Proc. 2nd Int. Cong. on Rock Mech. Ses. 8-14.

\section{要旨}

節理の任意に発達した節理系岩盤の力学的特性を明ら かにするため, 本研究ではまず応力伝達機構の立場から 光弾性実験による検証を含めて，こうした不連続体の数 值解析手法の可能性について論じた。

本研究ではこうした完全に離散化された不連続体に対 して，川井によって提案された剛体バネモデルを用いた 離散化有限要素解析をおこなった。この剛体バネモデル は離散化された要素自身については剛とし, 要素の境界 に分布する法線方向, 及び接線方向の 2 方向のバネでそ れらが結合されているという仮定のもとに解析をおこな うものである。このため材料特性が法線方向, 及び接線 方向の応力のみに関係するモール・クーロンの降伏基準 に従う場合には特に有効であり，本解析においても節理 面における降伏基準はモール・クーロンの直線式に従う ものとし，初期応力法に基づいた弾塑性解析をおこなっ た。そして計算結果は光弾性結果とかなり良く一致し， 任意深さの節理系地盤の応力分布性状についての解析が 可能であることが明らかとなった。

特に本研究では節理系岩盤の最も本質的な力学特性で ある，要素境界面でのすべり及び引張破壊現象を正確に 表わしうるよう，要素の分離及び再接触を考慮に入れた 弾塑性解析がなされた。そしてこうしたすべり及び引張 破壊領域が節理系岩盤の応力伝達機構を明らかにするの に有効であると思われる。これら節理系岩盤の応力分布 は節理形状及び拘束圧の大きさにより大きく変化し, 均 質連続体の応力状態とは相当異った性状を示す。これら のことから節理系岩盤の力学的特性を明らかにするには 節理系モデルの選択が極めて重要であるといえよう。

（昭和56年 4 月 21 日受理） 